\title{
SPECTROPHOTOMETRIC DETERMINATION OF ACTIVE COMPOUNDS IN AN ANTIHYPERTENSIVE FORMULATION BY HAAR-CWT METHOD
}

\author{
BIR ANTIHIIPERTANSIFF FORMÜLASYONDAKİ AKTIFF BILEŞIKLERIN HAAR-CWT \\ YÖNTEMIYLE SPEKTROFOTOMETRIK TAYINI
}

\author{
Özgür ÜSTÜNDAĞ $\breve{G}^{1, *}$ (D, Erdal DİNÇ \\ ${ }^{1}$ Ankara University, Faculty of Pharmacy, Department of Analytical Chemistry, 06560, Ankara, \\ Turkey
}

\begin{abstract}
Objective: In present work, we developed a new wavelet method (HAAR-CWT) to determine the amounts of irbesartan (IR) and hydrochlorotizide (HC) active compounds simultaneously in an antihypertensive formulation, and after validating this method, we successfully applied it to the assay of tablets containing the above-mentioned compounds.

Material and Method: The absorption spectra of mixtures and tablet solutions in the spectral range 200$305 \mathrm{~nm}$ were measured by a Shimadzu UV-1601 dual-beam UV-VIS spectrophotometer.

Result and Discussion: Due to the strong overlapping spectra of the mentioned components, the HAAR$C W T$ method has been proposed and successfully applied to the ratio spectra of IR-HC mixtures and tablets.
\end{abstract}

Keywords: Spectrophotometry, quantitative determination, wavelet transform, irbesartan, hydrochlorothiazide

ÖZ

Amaç: Bu çalışmada, bir antihipertansif formülasyondaki irbesartan (IR) ve hidroklorotizid (HC) aktif bileşiklerinin miktarlarını aynı anda belirlemek için yeni bir dalgacık yöntemi (HAAR-CWT) geliştirdik ve bu yöntemi doğruladıktan sonra, yukarıda bahsedilen bileşikleri içeren tabletlerin analizine başarıyla uyguladık.

Gereç ve Yöntem: 200-305 nm spektral aralı̆̆ındaki karışımların ve tablet çözeltilerinin absorpsiyon spektrumlarl, bir Shimadzu UV-1601 çift ışınlı UV-VIS spektrofotometresi ile ölçülmüş̧ür.

Sonuç ve Tartışma: Bahsedilen bileşenlerin güçlü şekilde örtüşen spektrumlarl nedeniyle, HAAR-CWT yöntemi önerilmiş ve IR-HC karışımlarının ve tabletlerinin oran spektrumlarına başarıyla uygulanmıştır.

Anahtar Kelimeler: Spektrofotometri, kantitatif tayin, dalgacık dönüşümü, irbesartan, hidroklorotiyazid

\footnotetext{
* Corresponding Author / Sorumlu Yazar: Özgür Üstündağ

e-mail / e-posta: ustundag@ pharmacy.ankara.edu.tr, Phone / Tel: +903122033171
} 


\section{INTRODUCTION}

Nowadays, researchers seek to meet the needs of better scientific measurements or to evolve more efficient procedures and increase the reliability of existing analytical methods to achieve the desired analytical results in many disciplines [1-3].

For analytical studies, LC and CE methods have been used in conjunction with different spectroscopic systems (separate techniques, namely LC-MS and CE-MS) to obtain more chemical data and reduce the complication of multicomponent substance analysis. Furthermore, these combined unit methods involve high costs and time for analysis [4-6]. Analytical methods such as spectrophotometry [7], mass-spectrometry [8], chromatography [9] and electrophoresis [10], electrochemistry [11] and their joint devices have been used for analytical purposes. Because of the disadvantages of the mentioned separation techniques or combination analyzers, analytical chemists opt to use spectroscopic methods (rather than separation techniques) to enable rapid analysis at low cost. Nowadays, applications of wavelet transform (CWT) methods to the spectrophotometric data gaining popularity because it can be used in the analysis of components in complex systems without the need for any separation process. Therefore, CWT methods can offer suitable solutions for such cases. [12-14]. Several analytical methods for the analysis of IR and HC have been reported in pharmaceutical and biological studies, including spectrophotometric methods [15-19] and chromatographic methods [20-23].

In this study, we focused on developing a wavelet transform method in order to perform simultaneous analysis of the specified active ingredients in a tablet formulation containing irbesartan and hydrochlorothiazide, without the need for a pre-separation method.

\section{MATERIAL AND METHOD}

The absorption spectra of mixtures and tablet solutions in the spectral range 200-305 $\mathrm{nm}$ were measured by a Shimadzu UV-1601 dual-beam UV-VIS spectrophotometer with a constant gap width (2 $\mathrm{nm}$ ). When applying the methods, Microsoft EXCEL and Wavelet Toolbox in Matlab 7.0 software were applied for calculations.

\section{Commercial Tablet Product}

A pharmaceutical tablet (KARVEZIDE® Tablet, Sanofi-Aventis. Ind., Istanbul, Turkey) including $150 \mathrm{mg}$ IR and $12.5 \mathrm{mg}$ HC per tablet was gathered from the Turkish market. IR and HC pure compounds were give away by National Pharm. Ind. Company, Turkey).

\section{Standard Solutions}

Standard IR and HC stock solutions were arranged respectively by dissolving $10 \mathrm{mg}$ of each drug in $100 \mathrm{~mL}$ of methanol. A calibration ranges between 4.0-32.0 $\mu \mathrm{g} \mathrm{ml}^{-1}$ for IR and 2.0-9.0 $\mu \mathrm{g} \mathrm{ml}^{-1} \mathrm{HC}$ in 
solvent was prepared for spectrum analysis from standard stock solutions for each active ingredient.

\section{Sample Solutions Preparation}

For testing tablets; twenty tablets of IR and HC were weighed and powdered. Transfer an equal amount of powder to a $100 \mathrm{ml}$ volumetric flask and solved with methanol. The contents of the flask were mechanically stirred. After filtration, the supernatant is diluted with methanol to an ultimate concentration. This pocedure was repeated ten times.

\section{RESULT AND DISCUSSION}

The purpose of this work is to apply the HAAR-CWT method to the ratio-spectra of IR and HC in mixtures and preparations for the simultaneous assay. The IR and HC standards and the UV spectra of the tablet solution were measured between 200 and $305 \mathrm{~nm}$ as can be seen in Figure 1 .

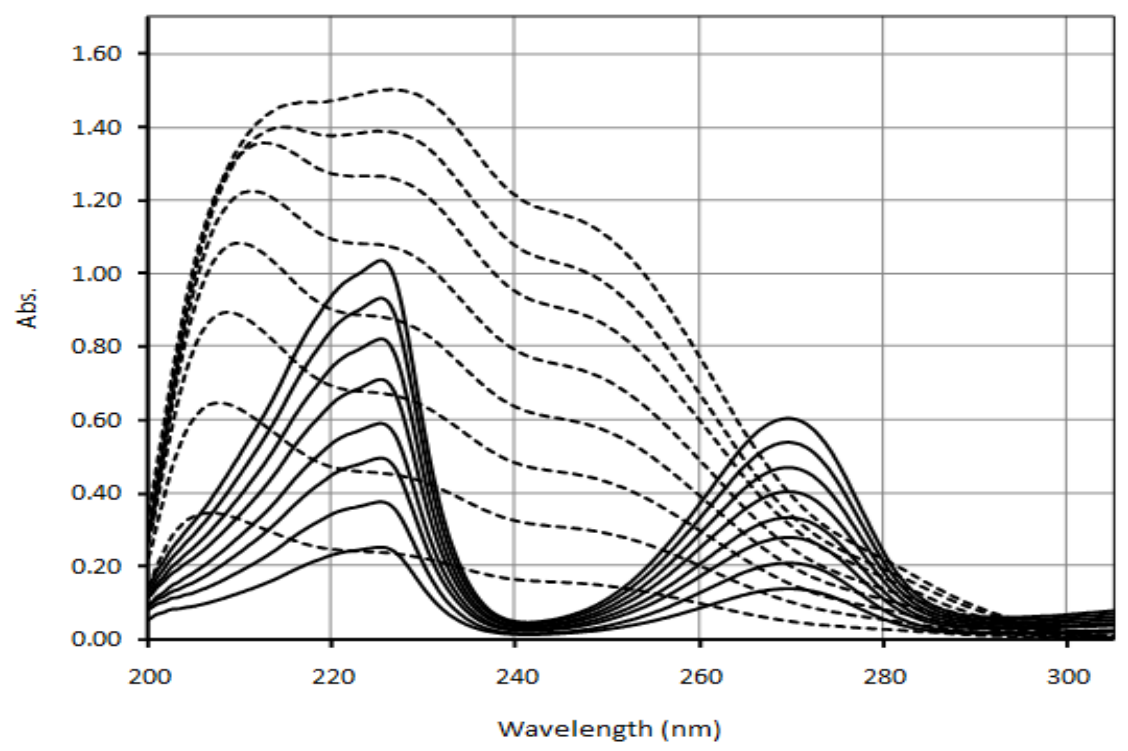

Figure 1. The UV-Absorption spectra of 4.0-32 $\mu \mathrm{g} \mathrm{mL}^{-1} \mathrm{IR}(---)$ and $2.0-9.0 \mu \mathrm{g} \mathrm{mL} \mathrm{g}^{-1} \mathrm{HC}(-)$ in methanol

\section{HAAR Continuous Wavelet Transform-Ratio Spectra Method (HAAR-CWT-RS)}

For the analysis of artificial mixtures and tablets containing IR and HC compounds by the HAARCWT-RS method, calibration mixtures were prepared as described in the above section, using methanol as a solvent in a linear concentration range of 4.0-32.0 $\mu \mathrm{g} \mathrm{mL}^{-1}$ for IR and 2.0-9.0 $\mu \mathrm{g} \mathrm{mL}^{-1}$ for HC. The original UV spectra of these calibration solutions were recorded in the 200-305 nm wavelength range with $\Delta \lambda=0.1 \mathrm{~nm}$ intervals and were coded and saved. The HAAR-CWT method applied to the ratio spectra of IR and HC (Figure 2 and Figure 3). Regression equation, correlation coefficient and their statistical data were shown in Table 1. The calibration equation of the HAAR-CWT-RS method was 
validated by using the quantitative assay of artificial mixtures. Recovery results and with relative standard deviation were shown in Table 2.

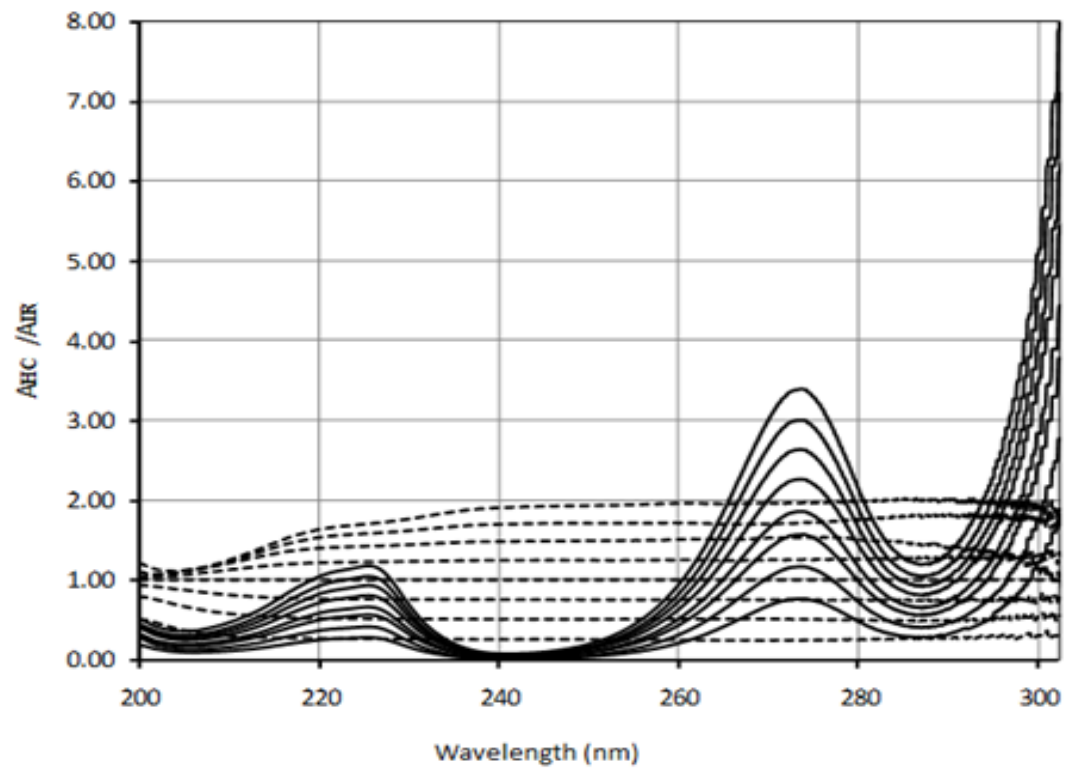

Figure 2. Ratio-spectra of IR (---) and HC (-) in methanol (Div: $\left.16 \mu \mathrm{g} \mathrm{mL}^{-1} \mathrm{IR}\right)$

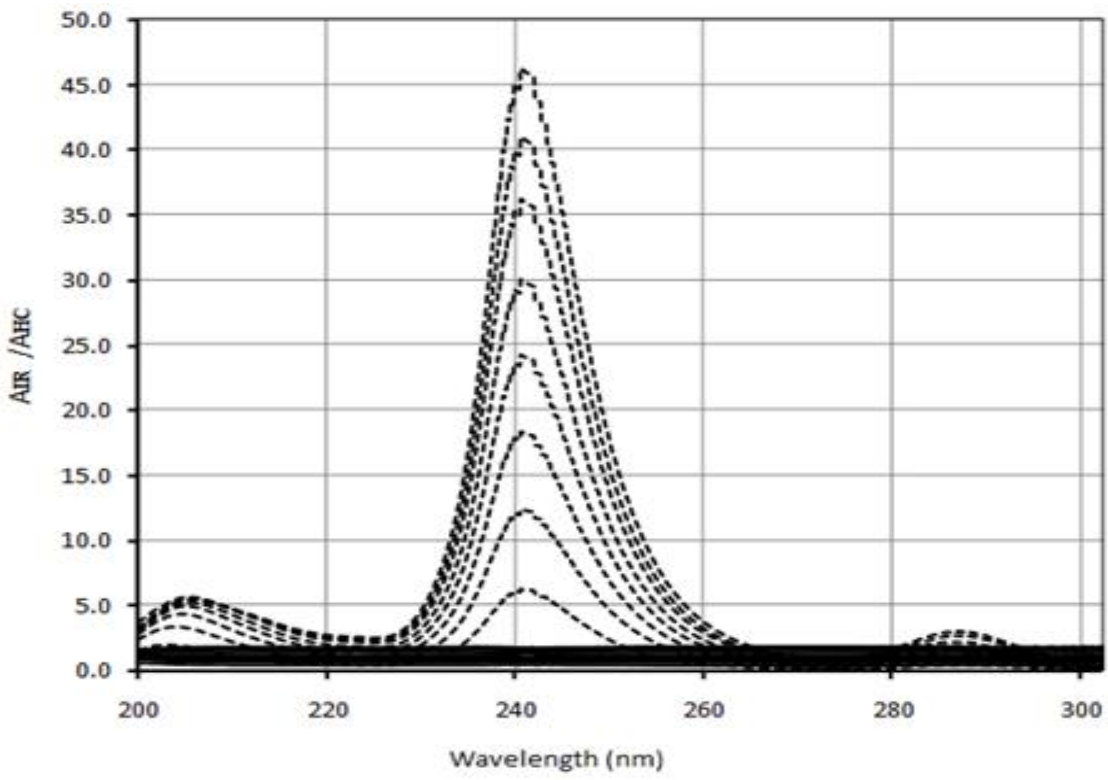

Figure 3. Ratio-spectra of IR (---) and $\mathrm{HC}(-)$ in methanol (Div: $4 \mu \mathrm{g} \mathrm{mL} \mathrm{L}^{-1} \mathrm{HC}$ )

The outcome of the regression analysis obtained are shown in Table 1. The amounts of IR and $\mathrm{HC}$ in the samples were computed using the calibration equations obtained from the linear regression analysis in Table 1. 
Table1. Statistical outcome for the HAAR-CWT-RS method

\begin{tabular}{|c|c|c|}
\hline Method & \multicolumn{2}{|c|}{ HAAR-CWT-RS } \\
\hline Parameter & IR & HC \\
\hline $\boldsymbol{\lambda}(\mathbf{n m})$ & 236.7 & 266 \\
& $\left(\right.$ Div $\left.: 4 \mu \mathrm{gL}^{-1} \mathrm{HC}\right)$ & $\left(\right.$ Div $\left.: 16 \mu \mathrm{gL}^{-1} \mathrm{IR}\right)$ \\
\hline $\mathbf{m}$ & -0.8931 & -0.0128 \\
\hline $\mathbf{n}$ & -0.6052 & -0.0128 \\
\hline $\mathbf{r}$ & 0.9997 & 0.9997 \\
\hline $\mathbf{S E}(\mathbf{m})$ & 0.0088 & 0.0012 \\
\hline $\mathbf{S E}(\mathbf{r})$ & 0.0588 & 0.0070 \\
\hline $\mathbf{L O D}(\mu \mathrm{g} \mathrm{mL}-1)$ & 0.0229 & 0.0076 \\
\hline $\mathbf{L O Q}\left(\mu \mathrm{g} \mathrm{mL}^{-1}\right)$ & 0.56 & 0.50 \\
\hline
\end{tabular}

$\mathrm{m}=$ Slope of the linear regression equation; $\mathrm{n}=$ Intercept of the linear regression equation; $\mathrm{r}=$ Correlation coefficient; $\mathrm{SE}(\mathrm{m})=$ Standard error of slope; $\mathrm{SE}(\mathrm{n})=$ Standard error of intercept; $\mathrm{SE}(\mathrm{r})=$ Standard error of correlation coefficient; LOD $=$ Limit of detection $\left(\mu \mathrm{g} \mathrm{mL}^{-1}\right) ; \mathrm{LOQ}=$ Limit of detection $\left(\mu \mathrm{g} \mathrm{mL}^{-1}\right)$

\section{Validation of the Proposed Methods}

A validation kit consisting of 16 artificial solutions of dissimilar concentrations in methanol in a working range of 4.0-36.0 $\mu \mathrm{g} \mathrm{ml}^{-1}$ for IR and 2.0-9.0 $\mu \mathrm{g} \mathrm{ml}^{-1} \mathrm{HC}$ was produced. This validation set tested the accuracy and precision of the HAAR-CWT-RS method. The results gathered by performing the HAAR-CWT-RS method to artificial mixtures prepared as a verification set are shown in Table 2.

Table 2. Recovery outcome calculated by using artificial mixtures

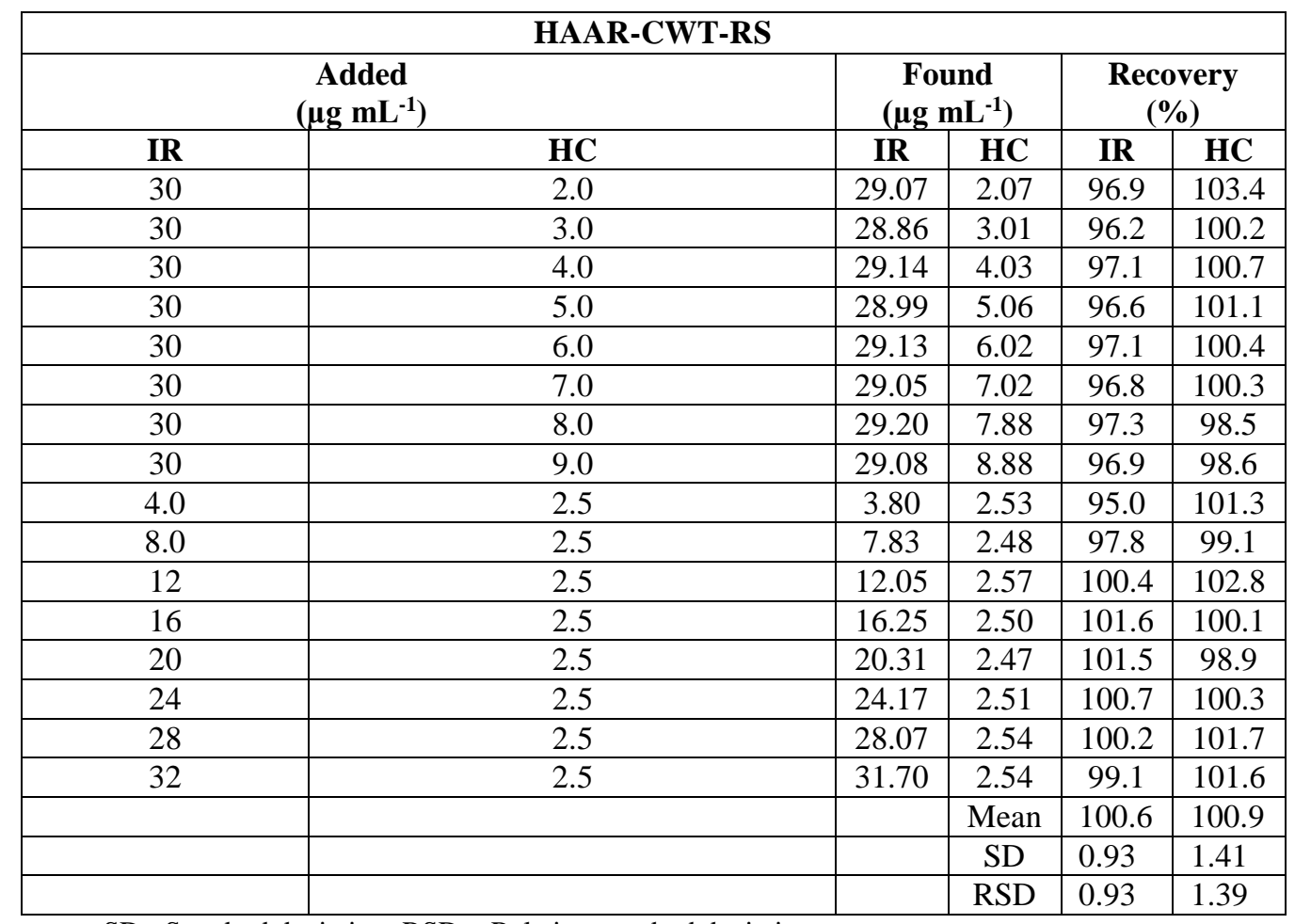

$\mathrm{SD}=$ Standard deviation; RSD = Relative standard deviation 
To appraise the accuracy and precision of the HAAR-CWT-RS method, precision and accuracy survey were applied daily at three dissimilar concentrations $\left(4,16\right.$ and $30 \mu \mathrm{g} \mathrm{ml}^{-1}$ for IR $-2,5$ and $8 \mu \mathrm{g}$ $\mathrm{ml}^{-1}$ for HC) during the calibration of the HAAR-CWT-RS method. Thus, 6 dissimilar solutions were used and the prepared solutions were used for intra-day and inter-day studies. The results can be seen in Table 3.

Table 3. Intra-day and inter-day outcome by the HAAR-CWT-RS method

\begin{tabular}{|c|c|c|c|c|c|c|}
\hline \multicolumn{7}{|c|}{ Intra-day Results } \\
\hline & $\begin{array}{c}\text { Added } \\
\left(\mu \mathrm{g} \mathrm{mL} \mathbf{L}^{-1}\right)\end{array}$ & $\begin{array}{c}\text { Found } \\
\left(\mu \mathrm{g} \mathrm{mL} L^{-1}\right)\end{array}$ & SD & RSD & $\mathbf{R E}$ & $\begin{array}{c}\text { Recovery } \\
(\%)\end{array}$ \\
\hline \multirow{3}{*}{ IR } & 4 & 3.91 & 0.07 & 1.69 & -2.27 & 97.7 \\
\hline & 16 & 15.88 & 0.15 & 0.94 & -0.74 & 99.3 \\
\hline & 30 & 29.69 & 0.39 & 1.32 & -1.02 & 100.1 \\
\hline \multirow{3}{*}{ HC } & 2 & 1.97 & 0.04 & 1.88 & -1.58 & 98.4 \\
\hline & 5 & 4.92 & 0.09 & 1.78 & -1.57 & 98.4 \\
\hline & 8 & 7.98 & 0.07 & 0.82 & -0.21 & 99.8 \\
\hline \multicolumn{7}{|c|}{ Inter-day Results } \\
\hline \multirow{3}{*}{ IR } & 4 & 3.96 & 0.05 & 1.31 & -1.02 & 99.0 \\
\hline & 16 & 15.82 & 0.13 & 0.84 & -1.13 & 98.9 \\
\hline & 30 & 29.30 & 0.13 & 0.45 & 2.33 & 97.7 \\
\hline \multirow{3}{*}{ HC } & 2 & 1.99 & 0.03 & 1.26 & 0.61 & 99.4 \\
\hline & 5 & 4.90 & 0.09 & 1.92 & -2.01 & 98.0 \\
\hline & 8 & 7.93 & 0.07 & 0.84 & -0.88 & 99.1 \\
\hline
\end{tabular}

$\mathrm{RE}=$ Percent relative error

Before the HAAR-CWT-RS method was implemented to the commercial tablet preparation, a standard addition technique was used to test the interference effects of tablet excipients on IR and HC. The results can be seen in Table 4 .

Recovery and other calculations for IR and HC were performed by subtracting the quantity of IR and $\mathrm{HC}$ from the tablets. These surveys were performed with five replicas at three dissimilar concentration grades. 


\section{Tablet Analysis}

The outcomes gathered by applying the proposed technique to the IR-HC commercial preparation solutions are shown in Table 5. Accomplished results have been gathered for the quantification of tablets containing IR and HC. In the determination of tablets, no interference with the tablet excipients in the determination of the concerned compounds was monitored when the HAAR-CWT-RS method was applied to commercially available tablets.

Table 4. Standard addition outcome by the HAAR-CWT-RS method

\begin{tabular}{|c|c|c|c|c|c|c|}
\hline & \multicolumn{3}{|c|}{ IR } & \multicolumn{3}{|c|}{$\mathrm{HC}$} \\
\hline & \multicolumn{6}{|c|}{ Added $\left(\mu \mathrm{g} \mathrm{mL}^{-1}\right)$} \\
\hline & 4 & 8 & 12 & 2 & 4 & 8 \\
\hline No. & \multicolumn{6}{|c|}{ Found $\left(\mu \mathrm{g} \mathrm{mL}^{-1}\right)$} \\
\hline 1 & 3.97 & 8.06 & 12.21 & 2.03 & 4.13 & 8.05 \\
\hline 2 & 4.02 & 8.27 & 12.40 & 2.05 & 4.13 & 7.99 \\
\hline 3 & 4.03 & 8.05 & 12.51 & 2.06 & 4.14 & 8.01 \\
\hline 4 & 3.95 & 8.13 & 12.35 & 2.09 & 4.07 & 8.02 \\
\hline 5 & 4.08 & 8.23 & 12.37 & 2.07 & 4.10 & 7.99 \\
\hline & \multicolumn{6}{|c|}{ Recovery (\%) } \\
\hline No. & \multicolumn{3}{|c|}{ IR } & \multicolumn{3}{|c|}{ HC } \\
\hline 1 & 99.3 & 100.8 & 101.7 & 101.6 & 103.3 & 100.6 \\
\hline 2 & 100.4 & 103.3 & 103.4 & 102.3 & 103.1 & 99.8 \\
\hline 3 & 100.7 & 100.6 & 104.2 & 103.1 & 103.4 & 100.1 \\
\hline 4 & 98.7 & 101.6 & 103.0 & 104.7 & 101.7 & 100.2 \\
\hline 5 & 102.0 & 102.9 & 103.1 & 103.7 & 102.6 & 99.9 \\
\hline Mean & 100.2 & 101.9 & 103.1 & 103.1 & 102.8 & 100.1 \\
\hline SD & 1.29 & 1.23 & 0.90 & 1.22 & 0.70 & 0.29 \\
\hline RSD & 1.29 & 1.21 & 0.87 & 1.18 & 0.68 & 0.29 \\
\hline $\mathrm{RE}$ & 0.24 & 1.85 & 3.06 & 3.08 & 2.82 & 0.13 \\
\hline
\end{tabular}

$\mathrm{RE}=$ Percent relative error 
To summarize the study briefly, the HAAR-CWT-RS method we have developed has been successfully applied to the spectral analysis of artificial mixtures and tablet formulations containing IR and HC. This method we have developed can be applied without requiring any pre-separation in cases where the spectra overlap each other in the same spectral region as in this study (see Figure 1). It was performed with analytical validation parameters to indicate the validity and applicability of the method.

\section{AUTHOR CONTRIBUTIONS}

Concept: $\ddot{O} . \ddot{U}$., E.D.; Design: $\ddot{O} . \ddot{U}$; Control: $\ddot{O} . \ddot{U}$;; Sources: $\ddot{O} . \ddot{U}$., E.D.; Materials: $\ddot{O} . \ddot{U}$., E.D.; Data Collection and/or processing: $\ddot{O} . \ddot{U}$.; Analysis and/or interpretation: $\ddot{O} . \ddot{U}$., E.D.; Literature review: $\ddot{O} . \ddot{U}$.; Manuscript writing: $\ddot{O} . \ddot{U}$., E.D.; Critical review: $\ddot{O} . \ddot{U}$.; Other: $\ddot{O} . \ddot{U}$. E.D.

\section{CONFLICT OF INTEREST}

The authors declare no conflict of interest.

\section{REFERENCES}

1. Siddiqui M. R., AlOthman Z. A., Rahman N. (2017) Analytical techniques in pharmaceutical analysis: A review. Arabian Journal of Chemistry, 10, 1409-1421. [CrossRef]

2. Valagaleti R., Burns P.K., Gill M. (2003) Analytical support for drug manufacturing in the United States-from active pharmaceutical ingredient synthesis to drug product shelf life. Drug Information Journal, 37, 407-438. [CrossRef]

3. Ju H. (2013) Grand challenges in analytical chemistry: towards more bright eyes for scientific research, social events and human health. Frontiers in Chemistry, 1:5. [CrossRef]

4. Chhonker Y. S., Edi C., Murry D. J. (2018) LC-MS/MS method for simultaneous determination of diethylcarbamazine, albendazole and albendazole metabolites in human plasma: Application to a clinical pharmacokinetic study. Journal of Pharmaceutical and Biomedical Analysis, 20-151, 8490. [CrossRef]

5. Sáiz J., García-Ruiz C., Gómara B. (2017) Comparison of different GC-MS configurations for the determination of prevalent drugs and related metabolites. Analytical Methods, 9, 2897-2908. [CrossRef]

6. Maurer H. H. (1994) Toxicological analysis of drugs: GC-MS screening and confirmation. Acta Medicince Legalis, XLIV, 489-492.

7. Rocha F. R. P., Teixeira L. S. G. (2004) Strategies to increase sensitivity in UV-VIS spectrophotometry. Quimica Nova, 27(5), 807-812. [CrossRef] 
8. Thiem T. L. (1994) Comparison of optical-emission mass-spectroscopy utilizing laser vaporization of solid samples for inorganic analysis. American Laboratory, 26(3), 48-52.

9. Deyl Z., Janak J., Schwarz V. (2001) Bibliography section - Liquid column chromatography - Gas chromatography - Planar chromatography - Gel chromatography - Capillary electrophoresis and electrokinetic chromatography. Journal Of Chromatography A, 940(2), 119-219.

10. Otieno A. C., Mwongela S. M. (2008) Capillary electrophoresis-based methods for the determination of lipids - A review. Analytica Chimica Acta, 624(2), 163-174. [CrossRef]

11. Naggar A. H., Kotb A., Abdelwahab A.A. (2021) Graphite studded with facile-synthesized $\mathrm{Cu}_{2} \mathrm{O}$ nanoparticle-based cubes as a novel electrochemical sensor for highly sensitive voltametric determination of mebeverine hydrochloride. Chemosensors. [CrossRef]

12. Daubechies I. (1992) Ten Lectures on Wavelets, Society for Industrial and Applied Mathematics, Philadelphia, 1-357.

13. Dinç E., Baleanu D. (2007) Continuous wavelet transform applied to the overlapping absorption signals and their ratio signals for the quantitative resolution of mixture of oxfendazole and oxyclozanide in bolus. Journal of Food and Drug Analysis., 15(2), 109-117. [CrossRef]

14. Üstündağ Ö., Dinç E. (2021) Continuous wavelet transforms and ultra performance liquid chromatography applied to the simultaneous quantitative determination of candesartan cilexetil and hydrochlorothiazide in tablets. Monatshefte für Chemie. [CrossRef]

15. Redasani V. K., Patel P. R., Marathe D.Y., Chaudhari S. R., Shirkhedkar A. A., Surana S. J. (2018) A review on derivative uv-spectrophotometry analysis of drugs in pharmaceutical formulations and biological samples review. Journal of the Chilean Chemical Society. [CrossRef]

16. Albero I., Rodenas V., Garcia S., Sanchez C. (2002) Determination of irbesartan in the presence of hydrochlorothiazide by derivative spectrophotometry. Journal of Pharmaceutical and Biomedical Analysis, 29(1-2), 299-305. [CrossRef]

17. El-Yazbi A., Hammud H., Sonji M. (2007) Analysis of eprosartan-hydrochlorothiazide and irbesartan -hydrochlorothiazide binary mixtures by derivative spectrophotometry. International Journal of Applied Chemistry,, 3(1), 1-12.

18. Joseph J., Brault S., Boyer C., Langlois M., Cabrero L., Dubost J. (2003) Simultaneous determination of irbesartan and hydrochlorothiazide in tablets by derivative spectrophotometry. Analytical. Letters, 36(11), 2485-2495. [CrossRef]

19. Kalyani G., Adjuad B. (2019) Stability indicating assay and estimation of irbesartan by first order uv derivative spectrophotometry. International Journal of Pharmaceutical Sciences and Research, 23, 3817-3821. [CrossRef]

20. Zhu J., You S., Meng X. (2003) Determination of irbesartan and hydrochlorothiazide in compound irbesartan tablets by HPLC. Zhongguo Yiyao Gongye Zazhi, 34(11), 567-569. 
21. Tutunji L. F., Tutunji M. F., Alzoubi M. I., Khabbas M. H., Arida A. I. (2009) Simultaneous determination of irbesartan and hydrochlorothiazide in human plasma using HPLC coupled with tandem mass spectrometry:Application to bioequivalence studies. Journal of Pharmaceutical and Biomedical Analysis, 51(4), 985-990. [CrossRef]

22. Alanazi A. M., Abdelhameed A. S., Khalil N.Y., Khan A. A., Darwish I. A. (2014) HPLC method with monolithic column for simultaneous determination of irbesartan and hydrochlorothiazide in tablets. Acta Pharmaceutica, 64, 187-198. [CrossRef]

23. Nalini C. N., Mathivanan N. (2020) A review on analytical methods of rrbesartan and its combinations in pharmaceutical dosage forms. Current Pharmaceutical Analysis, 16(8), 1020-1029. [CrossRef] 